\title{
Multidisciplinarity is Key on the Road to Improving Quality Cancer Care Throughout Europe
}

\author{
Philippe L. Pereira ${ }^{1}$ (D)
}

Received: 8 May 2020/ Accepted: 5 June 2020/Published online: 18 June 2020

(C) Springer Science+Business Media, LLC, part of Springer Nature and the Cardiovascular and Interventional Radiological Society of Europe (CIRSE) 2020

\section{Introduction}

For the past few decades, interventional radiologists have tirelessly applied their innovative spirit to create new treatment modalities in interventional oncology (IO), continuously improving minimally invasive, tumour-targeted percutaneous and arterial therapies to treat a wide range of malignancies. Supported by strong basic and clinical research, IO has therefore long moved from providing biopsies for diagnosis to offering therapies for the safe and effective treatment of primary and metastatic tumours, putting our daily practice on sound scientific ground.

CIRSE is supporting IO with numerous initiatives, including its dedicated annual congress ECIO, the European Curriculum and Syllabus in IO, its various registries, the Standards of Quality Assurance in IO document, and the current creation of the International Accreditation System of Interventional Oncology Services (IASIOS). In addition, CVIR dedicated a supplement exclusively to IO topics in September 2019.

Recognition of the various IO treatment modalities have picked up pace in recent years thanks to their wide acceptance in both the medical community and general population, largely based on the treatments being minimally-invasive, costeffective, ideally combined with systemic treatments or surgery, and leading to excellent quality of life outcomes.

This change in the perception of what IO has to offer has led, among others, to the fruitful cooperation with more than 20 cancer societies for the creation of each of the three following guidelines of the European CanCer Organisation (ECCO); ECCO Essential Requirements for Quality Cancer Care: Soft Tissue Sarcoma in Adults and Bone Sarcoma. A critical review [1], ECCO essential requirements for quality cancer care: Melanoma [2], and ECCO Essential Requirements for Quality Cancer Care: Colorectal Cancer. A critical review [3].

ECCO defines its essential requirements for quality cancer care (ERQCC) as "explanations and descriptions of challenges, organisation and actions that are necessary to give high-quality care to patients who have a specific type of cancer" [2]. Compiled by European experts from the various fields involved in the diagnosis and treatment of each specific cancer type, these documents provide guidelines to give tumour boards and healthcare managers an overview of what is required to guarantee the optimal patient pathway.

Philippe L. Pereira

Philippe.Pereira@slk-kliniken.de

1 Clinic for Radiology, Minimally-Invasive Therapies and Nuclear Medicine, SLK-Kliniken GmbH, Heilbronn, Germany 
All three of these guidelines point out that the treatment strategy for every cancer patient must be determined and carried out by multidisciplinary tumour boards (MDTs) consisting of - among others—-specialists from surgery/surgical oncology, medical oncology, pathology, radiology, nuclear medicine, radiation oncology, nursing, and interventional radiology.

The guidelines also identify the IO requirements for dedicated centres, pointing out that they must have experienced interventional radiologists with adequate training and practice on staff equipped with the appropriate tools and materials. Although IO therapies are now mentioned in several international guidelines, their importance and role are sometimes clearly underestimated, which does not necessarily reflect a political will, but may be the result of the absence of interventional radiologists in these committees.

\section{Conclusion}

Given Europe's rapidly ageing population, the incidence of most cancer types is bound to continuously increase, while at the same time the provision of cancer care varies greatly from country to country. We have to meet this challenge with universally agreed-upon documents to provide healthcare systems and institutions with guidance about how to create a framework that will allow optimal patient care for each given cancer type.

It is heartening to see that the hard work of interventional radiologists both in daily practice and on a political level are increasingly being recognised in national and international guidelines. IO is starting to receive the recognition it deserves, not only for the diagnosis of various malignancies, but also for the treatment of cancers through its great range of targeted chemotherapy, ablation and combined treatments.

However, much work remains to be done if we hope to achieve best possible cancer care for patients throughout Europe.

Funding This study was not supported by any funding.

\section{Compliance with Ethical Standards}

Conflict of interest P. Pereira is a grant recipient and speaker honoraria for Medtronic, Guerbet, Terumo Corporation, Pharmacept, Sirtex and has received financial as support from Angiodynamics, BTG and Schering.

Ethical Approval This article does not contain any studies with human participants performed by any of the authors.

Informed Consent For this type of study informed consent is not required.

Consent for Publication For this type of study consent for publication is not required.

\section{Reference}

1. Andritsch E, Beishon M, Bielack S, Bonvalot S, Casali P, Crul M, Delgado Bolton R, Donati DM, Douis H, Haas R, Hogendoorn P, Kozhaeva O, Lavender V, Lovey J, Negrouk A, Pereira P, Roca P, de Lempdes GR, Saarto T, van Berck B, Vassal G, Wartenberg M, Yared W, Costa A, Naredi P. ECCO essential requirements for quality cancer care: soft tissue sarcoma in adults and bone sarcoma. A critical review. Crit Rev Oncol Hematol. 2017;110:94-105.

2. Wouters MW, Michielin O, Bastiaannet E, Beishon M, Catalano O, Del Marmol V, Delgado-Bolton R, Dendale R, Trill MD, Ferrari A, Forsea AM, Kreckel H, Lövey J, Luyten G, Massi D, Mohr P, Oberst S, Pereira P, Prata JPP, Rutkowski P, Saarto T, Sheth S, SpurrierBernard G, Vuoristo MS, Costa A, Naredi P. ECCO essential requirements for quality cancer care: melanoma. Crit Rev Oncol Hematol. 2018;122:164-78.

3. Beets G, Sebag-Montefiore D, Andritsch E, Arnold D, Beishon M, Crul M, Dekker JW, Delgado Bolton R, Fléjou JF, Grisold W, Henning G, Laghi A, Lovey J, Negrouk A, Pereira P, Roca P, Saarto T, Seufferlein T, Taylor C, Ugolini G, Velde CV, Herck BV, Yared W, Costa A, Naredi P. ECCO essential requirements for quality cancer care: colorectal cancer. A critical review. Crit Rev Oncol Hematol. 2017;110:81-93.

Publisher's Note Springer Nature remains neutral with regard to jurisdictional claims in published maps and institutional affiliations. 